Статья посвящена малоизвестному, но информативному для истории советско-китайских отношений в межвоенный период эпизоду - разведывательной миссии бурятского большевика и коминтерновца С. А. Нацова в Синьцзяне осенью и зимой 1923 г. Рассматриваются биография этого незаурядного деятеля международного коммунистического движения, историко-политический контекст внутренней ситуации в Западном Китае, цели и задачи миссии и ход ее выполнения. Использованы малоизученные документы из фондов РГАСПИ о советско-синьцзянских отношениях в 1920-х гг. и синьцзянском вопросе в советско-монгольских и советско-китайских отношениях.

Ключевые слова: Коминтерн, Синьцзян, ойраты, калмыки, Внешняя Монголия, Китай, СССР, революционное движение, автономисты.

\title{
V. Yu. Bashkuev \\ THE XINJIANG MISSION OF S. A. NATSOV (1923). PART 1. A HISTORICAL AND POLITICAL CONTEXT
}

The article is devoted to an episode that is little-known, but informative for the history of the Soviet-Chinese relations in the interwar period - the reconnaissance mission of the Buryat Bolshevik and Comintern member S. A. Natsov to Xinjiang in autumn and winter of 1923. The biography of this remarkable figure of the international communist movement, the historical and political context of the domestic situation in Western China, the mission aims and objectives, and the course of its implementation are considered. We used the understudied documents from the funds of the RGASPI, which cover the Soviet-Xinjiang relations in the 1920s and the Xinjiang question in the Soviet-Mongolian and Soviet-Chinese relations.

Keywords: Comintern, Xinjiang, Oirats, Kalmyks, Outer Mongolia, China, USSR, revolutionary movement, autonomists.

\section{Введение}

$\mathbf{R}$ серии предыдущих публикаций о советской медико-санитарной помощи Монголии, Туве и странам Центральной Азии мною последовательно развивалась концепция ключевого значения Бурят-Монгольской АССР для азиатского вектора геополитики СССР в 1920-е гг. [Башкуев 2014; 2016а, б]. Находящиеся в Российском государственном архиве социально-политической истории (РГАСПИ) документы Исполкома Коминтерна (ф. 495) и Дальбюро ЦК РКП(б) (ф. 372) позволяют взглянуть на создание бурят-монгольской автономии как на геополитический проект для воздействия на монгольские народы вне пределов Советского Союза. Первые руководители Советского государства, БМАССР и деятели Коминтерна, поддерживавшие идею создания бурятской государственности в рамках советского эксперимента, отводили политическим активистам из бурят лидирующую роль в идеологической трансформации монгольских социумов. При этом география деятельности бурятских «агентов советского влияния» включала в себя населенные

БАШКУЕВ Всеволод Юрьевич - доктор исторических наук, ведущий научный сотрудник Федерального государственного бюджетного учреждения науки Институт монголоведения, буддологии и тибетологии СО РАН (г. Улан-Удэ, Россия). E-mail: seva91@yahoo.com. 
монгольскими племенами территории Барги, Внутренней Монголии и Синьцзяна. Вместе с уже подпавшими под советское влияние Внешней Монголией (MНР) и Урянхаем (ТНР) зона этого политического воздействия простиралась от Маньчжурии до Афганистана.

Дальнейшие исследования в фондах РГАСПИ показали, что помимо программных документов, обозначивших географические рамки, принципы и функции политической работы бурят в странах Азии, имеется ряд материалов, непосредственно иллюстрирующих их работу в указанных выше регионах. В предлагаемой статье речь пойдет о миссии представителя МНРП (и одновременно советника Восточного секретариата ИККИ при МНРП) С. А. Нацова (Шойжелова) в Синьцзяне в 1923 г. Развить эту тему позволяют несколько важных документов из фонда 514 «Коммунистическая партия Китая», в числе которых объемный доклад Нацова «Синьцзянская провинция, или Западный Китай». Он содержит этнографические материалы, подробный анализ политической системы и социальной ситуации в провинции. Другой документ под заглавием «Состояние вооруженных сил Синьцзянской провинции» описывает военный потенциал местного правительства и содержит детали, скорее присущие агентурным сводкам. Сохранилась и переписка С. А. Нацова с отделом Востока ИККИ, проливающая свет на цели и задачи миссии, общее целеполагание и стратегию Коминтерна в отношении Синьцзяна в начале 1920-х гг.

\section{C. А. Нацов (1898-1941) - большевик, агент и функционер Коминтерна}

В отличие от хорошо изученных в 1990-е гг. биографий ключевых деятелей бурятского нациестроительства (Э.-Д. Ринчино, Ц. Ж. Жамцарано, М. А. Амагаев, М. Н. Ербанов и др.), личность С. А. Нацова до сих пор остается в тени. Между тем богатая событиями жизнь и вклад в развитие международного коммунистического движения ставят его в один ряд с этими политическими фигурами. Но если героизированный (или, в зависимости от интерпретации, демонизированный) образ другого коминтерновца - Э.-Д. Ринчино - стал своего рода символом бурятского революционера, о Нацове, имевшем даже больший опыт международной революционной работы, написано лишь несколько статей в биографических сборниках. Период с 1923 по 1930 г. там обозначен как работа в Исполкоме Коминтерна и Исполкоме Коммунистического интернационала молодежи (КИМ). По-видимому, до полного рассекречивания фонда ИККИ информация о работе С. А. Нацова в Синьцзяне была недоступна исследователям, а позже волна научного интереса схлынула. Данная работа призвана заполнить эту лакуну.

Сирен Арабданович Шойжелов (Нацов) родился в 1898 г. в улусе Улбугай Тункинского района. На формирование его первых представлений о жизни сильно повлияла встреча с политическим ссыльным В. А. Денисовым. В семейной библиотеке Денисовых Сирен Шойжелов познакомился с сочинениями А. И. Герцена, Н. Г. Чернышевского, Н. А. Добролюбова [Нацов (Шойжелов) Сирен].

Общественная деятельность началась в Тункинском почтово-телеграфном отделении, где он трудился в 1917-1918 гг. Сначала Сирен Шойжелов сочувствовал РКП(б), затем вступил в партию и был искренним, идейным и активным большевиком. Взяв псевдоним «Нацов», он уже в 1920 г. стал секретарем Тункинского аймкома РКП(б). Однако бурятский период деятельности Нацова быстро закончился. В том же 1920 году партия направила его на пост политического комиссара Иркутского телеграфа. В Иркутске С. А. Нацов закончил партийную школу при 5-й армии, был заведующим отделом по делам национальностей Иркутского губкома РКП(б), а в 1921 г. был направлен Дальневосточным секретариатом Коминтерна в Монголию «для оказания помощи Народной партии» [Там же].

В Монголии ему пришлось не столько организовывать партийную работу, сколько воевать против остатков унгерновцев и китайских интервентов. Он при- 
нимал участие в боевых действиях в Западной Монголии и там познакомился с бытом и жизненными реалиями ойратов, сблизился с их лидерами. За храбрость С. А. Нацов был награжден орденом Боевого Красного Знамени [Нацов (Шойжелов) Сирен], в те годы высшей государственной наградой Советской России. В сентябре 1921 г. по заданию ЦК РКП(б) и Совнаркома РСФСР он был направлен на должность генконсула в Танну-Туве и параллельно являлся советником Восточного секретариата ИККИ при МНРП. Именно эта должность указана в его коминтерновских отчетах и докладах из Синьцзяна. В ИККИ Нацов работал с 1923 по 1930 г. и за этот период успел побыть представителем Коммунистического интернационала молодежи (КИМ) при Монгольском ревсомоле и представителем Коминтерна при ЦК Тувинской народно-революционной партии [Там же].

С сентября 1927 по 1930 г. по направлению Коминтерна С. А. Нацов обучался в международной Ленинской школе, по окончании которой был снова направлен в МНР на должность ответственного инструктора ЦК МНРП. Параллельно Нацов занимался журналистикой - был редактором журнала «Путь к социализму» и членом редколлегии правительственной газеты «Үнэн» [Там же].

В 1932 г. С. А. Нацов поступил в аспирантуру международной Ленинской школы [I]. Окончив ее, работал там же в должности доцента и заведующего отделом кадров. В 1935 г. его перевели на работу во Всемирный Интернационал профсоюзов на должность заведующего сектором кадров, а в 1936 г. - снова в Тувинскую Народную Республику советником при ЦК ТНРП [Нацов (Шойжелов) Сирен].

К сожалению, как это часто происходило в сталинский период, после возвращения в Москву из ТНР в августе 1938 г. С. А. Нацов был арестован и обвинен в создании контрреволюционной панмонгольской организации. Жизненный путь Сирена Арабдановича оборвался в июле 1941 г. Он был расстрелян на печально известном полигоне Коммунарка. Как человеку, долгое время занимавшемуся политическим объединением монголов Внутренней Азии для борьбы против мирового империализма, Нацову была вменена в вину его собственная работа. Идейный большевик и агент Коминтерна, внесший большой вклад в распространение коммунистической идеологии среди монгольских народов, С. А. Нацов был уничтожен системой, на которую так долго работал. Такую судьбу разделили тысячи профессионалов, создававших престиж и мощь Советской державы в самые критические годы ее существования.

Внешняя Монголия и освободительная борьба синьцзянских калмыков: историко-политический контекст взаимодействия

К 1759 г., после разгрома цинами Джунгарского ханства, огромная территория от границ Гоби до Ташкента опустела. Ойратов там почти не осталось: избежавшие геноцида остатки некогда могущественного народа (30-40 тыс. чел.) откочевали к соплеменникам в пределы Российской империи. Однако в 1770 г., на фоне усиления брожения низов на Урале, в Башкирии и казахских степях, калмыцкий наместник Убаши увел от 125 до 169 тыс. левобережных калмыков обратно в Синьцзян. Трагический поход, в котором от голода, холода, казахских и киргизских набегов было потеряно около 100 тыс. чел., закончился расселением оставшихся калмыков в пределах Цинской империи. Разделенные на 14 хошунов, синьцзянские монголы получили кочевья к востоку от г. Чугучака по р. Кобук, хр. Саур и восточной части Тарбагатайского хребта, в долине Большого и Малого Юлдусов, от северных склонов Тянь-Шаня через пустыню Цзосотын-Элисун до Уркашарского хребта, по северному склону хр. Боро-Хоро, от перевала Нилха до р. Таш. Часть калмыков поселили между верховьями р. Текес и Западным Тянь-Шанем. Последней группе были отведены пастбища по южному склону Тянь-Шаня, между долиной Большого и Малого Юлдуса и большой дорогой Токсун - Урумчи [Петров 2003: 127-129]. 
Калмыки (или, как их называют в Синьцзяне, калмаки) [II] с разрешения императора Цянь-Луна сохранили традиционную форму правления. Народом руководили князья и иерархи ламаистской церкви. В отличие от кочевников-тюрков, монголы пользовались налоговыми льготами, потому что являлись военнообязанными. Их специально расселяли в непосредственной близости от казахских кочевий в Тарбагатайско-Алтайском и Тянь-Шаньском регионах, чтобы в случае восстания кочевников-мусульман использовать против них монгольскую кавалерию.

Маньчжуры поддерживали многовековую вражду между монголами и кочевниками-тюрками, делая преференции одним и унижая других. Благодаря налоговым льготам синьцзянские монголы были существенно богаче казахов и киргизов. Так, сравнивая обычное движимое имущество калмыков и кочевников-тюрков, С. А. Нацов отмечал, что богатые монгольские скотоводы имеют около 5000 баранов, от 3000 до 5000 голов лошадей, до 3000 голов быков, в то время как богатые киргизы имеют от 500 до 2000 баранов, от 500 до 1000 лошадей и около 300 быков. Относящиеся к мелким скотоводам калмыки имели от 300 до 500 баранов, около 300 лошадей и от 100 до 200 быков. У бедных киргизов имущество состояло из 10-15 баранов, 2-3 лошадей и 5-10 быков [РГАСПИ. Ф. 514. Оп. 1. Д. 48. Л. 21].

Отношения с мусульманским населением Синьцзяна у калмыков были довольно напряженными. Из-за умело подогреваемой маньчжурами калмыцко-казахской вражды синьцзянские монголы всегда поддерживали цинов. Поэтому после свергнувшей династию Синьхайской революции 1911 г. глава ламаистов Синьцзяна Данцзан-Данби-хутухта обратился с посланием к монголам и калмыкам и призвал образовать на севере провинции независимое монгольское государство. Следуя призыву иерарха, торгуты, дербеты, олеты и чахары Илийской долины, служившие в китайских войсках, вышли из повиновения революционному комитету и начали нападать на его воинские части. К восстанию присоединился кобдоский торгутский князь Тохто (Тохтохо), пытавшийся при поддержке русских дипломатов объединить под своей властью Илийский, Тарбагатайский и Алтайский округа и присоединить их к Внешней Монголии. В Синьцзяне началась гражданская война [Петров 2003: 254].

М. Алпысбес и Д. Ергалиева выделяют две революционные группы синьцзянских монголов, сформировавшиеся сразу после Синьхайской революции. Одна группа базировалась в г. Карашаре, и ее лидером был регент Карашарского ханства Тойн-лама. Вторая существовала в Илийском округе. Возглавляли ее укердеи (или уккурдаи - правители сеймов). Обе группы были «автономистскими», а по сути панмонголистскими; выступали за формирование монгольского государства и его отделение от Китайской Республики; имели крепкие связи друг с другом; состояли преимущественно из офицеров и солдат китайских пограничных частей [2018: 90].

Подпольщики развернули активную деятельность: закупали оружие, агитировали против китайских властей, пытались установить отношения с третьими странами. Происходили и вооруженные выступления. Первое восстание подняли илийские монголы на р. Текес в 1912 г. Во главе восставших стоял князь Сумуй-бэйсэ. Скоро выступление было подавлено, а князь со своим хошуном бежал в Россию. Второе восстание разгорелось там же в 1914 г. Китайцы подавили его с помощью военной экспедиции. Шесть взятых в плен лидеров восстания вскоре были расстреляны в г. Куре [Там же: 92].

Одной из ключевых фигур революционных процессов второй декады XX в. был Дембрил, брат Сумуя-бэйсэ, в 1912 г. бежавший вместе с ним в Россию. Пробыв там некоторое время, Дембрил перебрался в Ургу, где прожил до Монгольской революции 1921 г. Дембрил хорошо разбирался в синьцзянских делах и мог представлять интересы как илийских монголов в Урге, так и МНРП, а значит, и Коминтерна в Синьцзяне. 
Отечественная история

В Монголии Дембрил вел переписку с правительством страны и соплеменниками в Илийском крае, прося у обретших независимость монголов Халхи оказать помощь угнетенным синьцзянским соплеменникам. Критически оценивая Кяхтинский договор 1915 г., Дембрил уповал на изменение политического вектора после Монгольской революции 1921 г. «За последние годы, - писал он, - среди народов мира стали распространяться идеи о самоопределении каждого племени с сохранением своих религиозных учений и народы повели борьбу за освобождение от всяких насилий для создания демократической народной власти. К этому движению примкнул монгольский народ и организовал Народное Правительство. Ввиду этого, все взоры и упования монгольских племен обращены в сторону этого государства, веря, что подобно рекам, впадающим в море, сольются в одно целое монгольские народы» [РГАСПИ. Ф. 514. ОП. 1. Д. 27. Л. 11].

В 1922 г. дело Дембрила активно поддержал Э.-Д. Ринчино, в политических воззрениях которого идеи панмонголизма занимали важное место. Мысля геополитически, коминтерновец Ринчино взаимодействовал с Дембрилом и через него с 11 сеймами илийских монголов, стараясь как можно точно прощупать ситуацию в крае. Дело в том, что представители Среднеолетского сейма и 10 других районов Илийского края обратились к монгольскому правительству с просьбой об оказании военной помощи и принятии их в подданство. Шанс взбунтовать илийских монголов против китайской власти с их возможным отделением от Синьцзяна и присоединением к Монголии напрямую резонировал с мыслью, высказанной Ринчино в часто цитируемом письме «В Буробком РКП» от 23 октября 1924 г. Там он писал, что образование Бурят-Монгольской АССР и Монгольской республики повернуло внимание почти всех монгольских племен (Барги, Внутренней Монголии и Китайского Туркестана) к Коминтерну и СССР и что вслед за монголами туда же тянется многомиллионная масса китайских мусульман [Башкуев и др. 2016: 160].

В телеграмме заведующему отделом Дальнего Востока Наркомата иностранных дел РСФСР Духовскому Э.-Д. Ринчино обозначил геополитические перспективы поддержки синьцзянских монголов для Советской России и Монголии. Во-первых, он считал, что восставших можно использовать как рычаг давления в переговорах с Пекином, а также в качестве ролевой модели для других народов Востока, в особенности тибетцев, связь с которыми у синьцзянских монголов была теснее, чем у Внешней Монголии. Во-вторых, Ринчино опасался, что в случае отказа в помощи это вызовет резко негативные настроения у илийских монголов и образовавшийся вакуум займет третья сторона, враждебная Советской России и Монголии, тем более что попытки снестись с Великобританией предпринимались еще в 1919 г., когда уккурдай Среднеолетского сейма Насон-Бату пытался связаться с английским правительством, но, не зная языка, потерпел неудачу [РГАСПИ. Ф. 514. Оп. 1. Д. 27. Л. 3,11$]$. Это непреложное геополитическое правило впоследствии очень беспокоило сталинское руководство, с середины 1920-х гг. наращивавшее экономическое присутствие в провинции и к концу 1930-х гг. фактически превратившее ее в советский сателлит.

Монгольское правительство все-таки пошло навстречу просьбам илийских собратьев. В Синьцзян с заданием собрать подпольный съезд калмыцких лидеров и установить связь с революционными мусульманскими организациями был командирован Дембрил. Ему удалось получить письменные заверения о готовности к восстанию от уккурдаев 11 илийских сеймов. Весной и летом 1922 г. особая (судя по всему - подпольная) делегация вела разведывательную работу в Синьцзяне. В основном собирались сведения военного характера. Подсчитывались войска, которыми располагали китайские администраторы, оценивалось их вооружение и общая боеспособность. Синьцзянские монголы вели серьезную подготовку к восстанию против Китайской республики, и командиры монгольских частей письменно подтвердили свою готовность выступить в любой момент. 
По данным М. Алпысбес и Д. Ергалиевой, восстание было назначено на апрельмай 1923 г. Черновой сценарий выглядел так: монгольские войска с территории Кобдоского и Дзасакту-хановского аймаков начинают наступление на Гучен и Урумчи. Одновременно в китайском тылу, особенно в городах, автономисты поднимают восстания под предлогом требований хлеба для безработных и голодающих [2018: 94].

Для выполнения плана илийские монголы запрашивали у правительства Внешней Монголии значительные военные ресурсы: 20 тыс. винтовок с 10 тыс. патронов на каждую; 20 орудий с сотней снарядов на каждое; по два броневика и аэроплана, а также 4000 цириков Народно-революционной армии [РГАСПИ. Ф. 514. Оп. 1. Д. 27. Л. 7]. Вряд ли летом 1922 г. монгольская сторона могла предоставить все это вооружение и войска. Поэтому, «желая сделать РСФСР серьезные предложения [по] Киттуркестанскому вопросу и ввиду необходимости окончательного оформления передачи оружия и возмещения его стоимости...», монгольское правительство информировало НКИД РСФСР о готовящейся чрезвычайной миссии в Москву в составе Э.-Д. Ринчино и помглавкома Хатан-Батора Максаржава [Там же. Л. 2]. Не вызывает сомнения тот факт, что решение всецело зависело от Москвы, а Ринчино, будучи председателем Реввоенсовета Монголии, играл в этом процессе ведущую роль.

Однако китайцы тоже вели встречную секретную работу по выявлению и нейтрализации монгольских революционеров и купированию инсургентских настроений среди синьцзянских монголов. Эта деятельность была успешной. Дембрил признавал грозящую ему и другим подпольщикам опасность из-за огромного количества китайских шпионов, внедренных в монгольские массы. Он призывал рассылать уполномоченных с документами по сеймам, а не собираться вместе, чтобы минимизировать угрозу ареста [Там же. Л. 8-8об.].

Китайцам удавалось даже перехватывать караваны с оружием, предназначенным для повстанцев. Так, в октябре 1922 г. в степи в 100 верстах южнее г. Урумчи был захвачен караван из Тибета, направлявшийся к карашарскому хану. Были взяты 80 винтовок и два сопровождающих монгола. После страшных пыток, в ходе которых китайцам не удалось получить нужную информацию, они были расстреляны [Алпысбес, Ергалиева 2018: 95].

Таким образом, несмотря на решимость синьцзянских монголов освободиться от китайской власти и присоединиться к Монголии, задача эта была чрезвычайно сложна и требовала учета множества факторов. Дело, главным образом, упиралось в геополитические реалии начала 1920-х гг. Советская Россия, только что вышедшая из кровопролитной гражданской войны, могла помочь, но была вынуждена сконцентрироваться на собственных глубоких социальных и экономических проблемах. Синьцзянские монголы были серьезной силой, способной выставить несколько тысяч подготовленных бойцов, но в политическом плане они еще не определились и не имели общей организации, что снижало шансы на одновременность и успех восстания. Поэтому для изучения ситуации на месте в Синьцзян был направлен С. А. Нацов - коминтерновец под прикрытием, знающий монгольский язык, обычаи и реалии, идеологически полностью надежный и управляемый.

\section{Миссия С. А. Нацова в Синьцзяне: цели, задачи и ход работы}

Цели миссии С. А. Нацова в Синьцзян несколько проясняются после ознакомления с его письмом заведующему отделом Среднего Востока НКИД СССР Цукерману от 1 октября 1923 г. Документ содержит прямые свидетельства того, что основной задачей Нацова являлась разведывательная деятельность под прикрытием статуса второго секретаря Кульджинского представительства НКИД СССР. Соответствующим мандатом его снабдил Михайлов из Среднеазиатского бюро РКП(б) [РГАСПИ. Ф. 514. ОП. 1. Д. 48. Л. 78]. 
Отечественная история

25 сентября 1923 г. Нацов, Дембрил и Насон-Бату прибыли в Ташкент, а на следующий день Сирен Арабданович отправился в Среднеазиатское бюро РКП(б) для встречи с Михайловым, по-видимому, отвечавшим за такого рода предприятия. Нацов изложил ему свои планы на поездку и выразил беспокойство по поводу Дембрила. Тот, вероятно, отличался авантюризмом и склонностью к интригам. Чтобы нейтрализовать эту опасность в атмосфере тотальной слежки, устроенной китайцами, Нацов предложил под благовидным предлогом отправить Дембрила в Ургу. Был разработан план: оставив в тайне встречу 26 сентября, на следующий день Нацов должен был, как ни в чем ни бывало, представить себя и монголов руководству Среднеазиатского бюро РКП(б). Накануне он проинформировал Михайлова об опасной ситуации, сложившейся в Кульдже: китайцы знали не только о готовящемся восстании, но и о будущем визите Дембрила и ждали его. Михайлов должен был по большому секрету «ошеломить» монголов этим печальным известием и предложить Дембрилу для безопасности остаться в Ташкенте [РГАСПИ. Ф. 514. ОП. 1. Д. 48. Л. 75об.].

Операция по дезинформации прошла даже лучше, чем ожидалось. В произошедшем после очередного визита в Среднеазиатское бюро РКП(б) обсуждении монголы - спутники Нацова высказались за исполнение плана Михайлова с одним нюансом. Дембрил получил возможность вернуться в Ургу, чтобы поправить здоровье вследствие обострившегося хронического заболевания. С ним Нацов отправил денежную отчетность и письмо в ЦК МНРП. Также он обсудил с НасонБату и Дембрилом варианты того, как китайцы узнали о планах визита Дембрила в Кульджу. По мнению илийских монголов, расконспирация произошла в результате предательства кого-то из информированных чиновников в Урге. Нацов посоветовал Дембрилу по прибытии в Ургу сделать доклад по этому вопросу в ЦК МНРП [Там же. Л. 77-77об.].

С. А. Нацов прибыл в Кульджу 5 ноября 1923 г. Наван-Бату остался в Алма-Ате, откуда через сумбун-караул на советско-китайской границе должен был пробраться к илийским монголам для сбора сведений о революционной активности. Собрав информацию, он должен был прибыть в Кульджу и встретиться с Нацовым через уйгурских подпольщиков.

В Кульдже С. А. Нацов собирал сведения об активности не только монгольских автономистов, но и уйгурских революционеров. 21 ноября в город тайно прибыл Наван-Бату вместе с лидером автономистов Лижи. Через руководителя уйгурского подполья Зайналова Нацов встретился с монголами, а впоследствии не раз встречался и с другими лидерами синьцзянских подпольных революционных ячеек. На основе полученной в Синьцзяне информации был составлен объемный отчет, которому будет посвящена отдельная статья [III]. Кроме того, в документах Нацова имеются расшифровки секретных телеграмм и приказов синьцзянского дуцзюна (генерал-губернатора) Ян Цзэсиня тарбагатайским и илийским даоиням (окружным начальникам) [РГАСПИ. Ф. 514. ОП. 1. Д. 48. Л. 83-96]. Это означает, что у революционеров были свои люди на телеграфе и в администрации даоиней или самого дуцзюна, а у Нацова - доступ к полученным разведданным.

В письме заведующему отделом Дальнего Востока ИККИ Лойтинскому С. А. Нацов сообщал, что во время конспиративных встреч руководители синьцзянского подполья были тщательно проинструктированы о недопустимости «каких бы то ни было авантюристических выступлений» [Там же. Л. 128]. Склонность Дембрила именно к таким действиям ранее внушала опасения Нацову.

Также С. А. Нацов обратился к Лойтинскому с просьбой о завершении миссии, так как основные цели - сбор информации и недопущение неконтролируемых «авантюрных» выступлений монгольских автономистов были успешно достигнуты. Он сослался на растущий риск со стороны китайских шпиков и особенно бело- 
эмигрантов. «...Китайцы, великолепно зная меня как одного из бывших активных работников западно-монгольского революционного движения, - писал Нацов, - уже с момента моего прибытия сюда не оставляли меня своим благосклонным вниманием, очень тщательно окружили меня своими шпиками, как китайцами, так и русскими белогвардейцами» [РГАСПИ. Ф. 514. Оп. 1. Д. 48. Л. 128об.]. Он выражал опасение, что у кого-нибудь из приставленных шпиков рано или поздно возникнет желание попытаться «из-за угла угостить пулей» коминтерновского агента [Там же. Л. 129].

Составленный С. А. Нацовым обширный доклад о положении в Синьцзяне долго являлся основным источником информации о провинции, так как в разных вариантах (полном и несколько сокращенном) неоднократно встречается в делах фонда 514 «Коммунистическая партия Китая». Этот документ заслуживает отдельного исследования и будет подробно проанализирован в последующих публикациях.

\section{Заключение}

Миссия С. А. Нацова в Синьцзяне, несмотря на свою краткость, дала важные результаты. Была из первых рук получена информация о революционном движении в провинции, размещении китайских и лояльных местному правительству войск и их боеспособности, планах китайцев относительно монгольского и уйгурского националистического подполья. Произошло знакомство со многими лидерами подпольщиков, в ходе которого до них была доведена позиция Москвы о недопущении «авантюрных» (по-видимому самостоятельных, не контролируемых ни Коминтерном, ни Монголией) выступлений. Уже тогда начали вырисовываться контуры политики СССР в отношении синьцзянских инсургентов: сдерживание вспышек насилия и непродуманных выступлений на фоне формального одобрения и обещания поддержки. Следует сказать, что вплоть до начала 1950-х гг. СССР тайно поддерживал китайскую администрацию Синьцзяна, избегая появления в провинции панисламистского движения, способного перекинуться в советскую Среднюю Азию.

Сам С. А. Нацов, работавший под двумя прикрытиями (представителя МНРП и второго секретаря представительства НКИД СССР в Кульдже), представлял собой типичного законспирированного советского агента. Работая на Коминтерн, он сохранял связи с Наркоматом иностранных дел СССР и, возможно, с другими «уполномоченными организациями». Такая «многозадачность» и «многостаночность» была характерна для многих работников советских представительств за рубежом, в т. ч. и Наркомздрава РСФСР и Союза Красного Креста и Красного Полумесяца.

Характеристики различных групп населения Синьцзяна, особенности социального устройства, экономического и военного положения, состояние национального вопроса в провинции подробно представлены в докладе С. А. Нацова «Синьцзянская провинция или Западный Китай». Его анализу будет посвящена статья в следующем номере «Вестника Бурятского научного центра СО РАН».

Статья подготовлена в рамках государственного задания (проект «Россия и Внутренняя Азия: динамика геополитического, сочиально-экономического и межкультурного взаимодействия (XVII-XXI вв.)») № 121031000243-5.

\section{Примечание}

I. Международная Ленинская школа (МЛШ) была создана в Москве в мае 1925 г. по решению V Конгресса Коминтерна (1924 г.). Готовила кадры для коммунистических партий и аппарата Коминтерна. Прекратила деятельность в сентябре 1938 г. [Международная Ленинская школа...].

II. В. И. Петров приводит интересную этимологию этнонима «калмак». Производное от тюркского глагола «калма» (не оставайся, не отставай) прозвище калмак родилось в среде тюркских купцов, водивших караваны по всей Центральной Азии и не раз подвергавшихся 
нападениям воинственных ойратов. По его версии, слово «калмак» имеет значение «неотстающий», а в арго караванщиков, возможно, это было поведенческое понятие «пристал - не отстанет») [2003: 125].

III. В настоящее время редколлегией данного журнала запланирована серия из трех статей, посвященных деятельности С. А. Нацова в Синьцзяне. После данной статьи выйдут еще две работы с анализом материалов миссии Нацова. Одна из них посвящена докладу «Синьцзянская провинция или Западный Китай», другая - документу «Состояние вооруженных сил Синьцзянской провинции».

\section{Источник и литература}

Российский государственный архив социально-политической истории (РГАСПИ): ф. 514 «Коммунистическая партия Китая», оп. 1, д. 27, 48.

Алпысбес М. Военно-политическое положение синьцзянских монголов в 1910-х - нач. 1920-х гг. / М. Алпысбес, Д. Ергалиева // Алтаистика, тюркология, монголистика. - 2018. № 2. - C. 89-96.

Башкуев В. Ю. Геополитика и евгеника в контексте научного изучения БурятМонгольской АССР в 1920-х - 1930-х гг. / В. Ю. Башкуев // Власть. - 2014. - № 5. C. $140-145$.

Башкуев B. Ю. Российская медицина и монгольский мир: исторический опыт взаимодействия (конец XIX - первая половина XX вв.) / В. Ю. Башкуев. - Иркутск: Оттиск, 2016. - $436 \mathrm{c}$.

Башкуев В. Ю. Геомедицина и политика здравоохранения в Байкальском регионе: история и современность / В. Ю. Башкуев, Е. Ю. Башкуева, Б. З. Нанзатов, М. М. Содномпилова, У. В. Башкуева. - Иркутск: Оттиск, 2016. - 306 с.

Международная Ленинская школа (МЛШ) (1925-1938) [Электронный ресурс]. - Режим доступа: https:/guides.rusarchives.ru/node/21472 (дата обращения: 26.04.2021).

Нацов (Шойжелов) Сирен [Электронный ресурс]. - Режим доступа: http://soyol.ru/personas/figures/688/ (дата обращения: 21.04.2021).

Петров В. И. Мятежное «сердце» Азии: Синьцзян: краткая история народных движений и воспоминания / В. И. Петров. - М.: Крафт+, 2003. - 528 с.

\section{References}

Rossijskij gosudarstvennyj arhiv social'no-politicheskoj istorii (RGASPI): f. 514 «Kommunisticheskaya partiya Kitaya», op. 1, d. 27, 48.

Alpysbes M. Voenno-politicheskoe polozhenie sin'czyanskih mongolov v 1910-h - nach. 1920-h gg. / M. Alpysbes, D. Ergalieva // Altaistika, tyurkologiya, mongolistika. - 2018. - № 2. - S. 89-96.

Bashkuev V. Yu. Geopolitika i evgenika v kontekste nauchnogo izucheniya Buryat-Mongol'skoj ASSR v 1920-h - 1930-h gg. / V. Yu. Bashkuev // Vlast’. - 2014. - № 5. - S. 140-145.

Bashkuev V. Yu. Rossijskaya medicina i mongol'skij mir: istoricheskij opyt vzaimodejstviya (konec XIX - pervaya polovina XX vv.) / V. Yu. Bashkuev. - Irkutsk: Ottisk, 2016. - $436 \mathrm{~s}$.

Bashkuev V. Yu. Geomedicina i politika zdravoohraneniya v Bajkal'skom regione: istoriya i sovremennost' / V. Yu. Bashkuev, E. Yu. Bashkueva, B. Z. Nanzatov, M. M. Sodnompilova, U. V. Bashkueva. - Irkutsk: Ottisk, 2016. - 306 s.

Mezhdunarodnaya Leninskaya shkola (MLSh) (1925-1938) [Elektronnyj resurs]. - Rezhim dostupa: https://guides.rusarchives.ru/node/21472 (data obrashcheniya: 26.04.2021).

Nacov (Shojzhelov) Siren [Elektronnyj resurs]. - Rezhim dostupa: http://soyol.ru/personas/ figures/688/ (data obrashcheniya: 21.04.2021).

Petrov V. I. Myatezhnoe «serdce» Azii: Sin'czyan: kratkaya istoriya narodnyh dvizhenij i vospominaniya / V. I. Petrov. - M.: Kraft+, 2003. - 528 s. 